\title{
$\angle S$ Research Square \\ Physicochemical and microbiological dynamics in composting of organic waste using a new bioreactor model
}

\section{Suelen Gaspar}

Universidade Federal de Lavras Departamento de Biologia

\section{Lucas Assis}

Universidade Federal de Lavras Departamento de Ciencia do Solo

\section{carla Carvalho}

Universidade Federal de Lavras Departamento de Biologia

\section{Gustavo Ferreira}

Universidade Federal de Itajuba

\section{Rosane Schwan}

Universidade Federal de Lavras Departamento de Biologia

\section{Moacir Pasqual}

Universidade Federal de Lavras Departamento de Agricultura

JOYCE DORIA ( $\boldsymbol{\sigma}$ joyce.doria@ufla.br)

Universidade Federal de Lavras Departamento de Agricultura https://orcid.org/0000-0002-7727-5016

\section{Original article}

Keywords: Bioreactor, composter, inoculants, microorganisms, organic matter, temperature

Posted Date: May 4th, 2020

DOl: https://doi.org/10.21203/rs.3.rs-22350/v1

License: (9) This work is licensed under a Creative Commons Attribution 4.0 International License. Read Full License 


\section{Abstract \\ Background}

It is important to use renewable resources to minimize the environmental risks and the composting is one of the most sustainable methods for the management of organic waste.

\section{Methods}

The objective of this work was to evaluate the physicochemical dynamics of microorganisms and to study cultivable microorganisms during the composting process of organic residues in a new model of bioreactor. The formulation of a possible cocktail of microorganisms selected for use as a compound accelerator will be further investigated. In addition, the use of two inoculants (non-commercial inoculum $(\mathrm{NCl})$ ) and commercial inoculum $(\mathrm{Cl})$ ) and a control without inoculant during the composting process will be analyzed to evaluate its efficiency. Composting was performed by mixing organic waste from the garden waste and University Restaurant, obtaining an ideal $\mathrm{C} / \mathrm{N}$ ratio of 30:1. The composting process was carried out in $1 \mathrm{~m}^{3}$ composters with controlled temperature and aeration.

\section{Results}

The thermophilic phase for all treatments was reached by the second day. Mature compost was obtained after an average of 120 days and composting in all treatments showed an increase in the availability of $P$ and micronutrients. During composting, the population of bacteria and actinobacteria were higher than those of yeasts and filamentous fungi.

\section{Conclusions}

Increased composting efficiency was observed when starter cultures were used, the treatments presented advantages such as greater mineralization of P-available and micronutrients as $\mathrm{Mn}$ and $\mathrm{Zn}$, in terms of the quality of the final product in comparison to the control treatment.

\section{Background}

Food scraps and organic wastes are considered as the largest components of urban solid waste and account for approximately $55 \%$ of total waste in developing countries, which face greater challenges with food waste management $[1,2]$. The treatment of organic waste is a serious and urgent matter, and since such waste negatively affects environmental quality, sustainable technologies must be implemented to reduce the environmental threat of organic waste [3]. 
Organic waste treatment methods commonly used in developing countries include use as feed (rare), compost (1 to $6 \%)$, anaerobic digestion ( $<0.6 \%)$, incineration and/or landfills ( $>90 \%)$ [1]. There have been several studies on composted materials, such as biogas slurry and cow manure [4], digested sludge mixed with mature compost and sawdust [5], green waste with spent mushroom compost and biochar [6], cattle manure and rice straw [7], and flower waste [8].

Compost produced for agricultural use from food waste has received considerable interest [9][9]. Beyond that, the composting can contribute toward huge $\mathrm{CO}_{2}$ and energy consumption reduction [10].

Composting involves the transformation of organic matter through the rapid succession of microbial populations into a stabilized product and is considered as an efficient and inexpensive technology for the recycling of organic waste [11].

During the composting process, specific parameters are important to monitor the process and ensure that a final quality product is obtained, such as the $\mathrm{C} / \mathrm{N}$ ratio, oxygen availability, $\mathrm{pH}$, temperature, aeration, humidity, particle size, fermentation and presence of humic acid that is usually produced at the end of the composting process [12-14] Traditional composting involves problems such as inadequate ventilation, uneven mixing, and other challenges, and these disadvantages can be reduced by using reactors that help control the process and provide optimal conditions for quality compost $[15,16]$. In addition, pile turning during the degradation stage is key parameter to maintain microbial diversity and, to some extent, the population profile present at the beginning of the process [17].

The physicochemical characterization of organic and food residues used in composting processes, could help to determine the level of biodegradation of these residues and these data can be useful to demonstrate the possible maturation phase of composting, which provides a better and more accurate agricultural application [18].

The composting occurs with natural microbiota including bacteria, actinobacteria, yeasts and filamentous fungi, which are generally involved in the degradation of lignocellulosic components during aerobic composting [19][19]. The addition of starter cultures at the beginning of the process can lead to substantial improvement in the waste degradation rate [20-23].

During the composting process, there is a change in temperature due to the biological activity of microorganisms classified as mesophilic $\left(15-45^{\circ} \mathrm{C}\right)$, thermophilic $\left(45-80^{\circ} \mathrm{C}\right)$ and hyperthermophilic (> $80^{\circ} \mathrm{C}$ ) [24]. During the thermophilic and hyperthermophilic phase, normally actinobacteria and grampositive bacteria are observed [25], occurring the suppression of several pathogens [26]. After this phase, occur the stabilization of compost temperature and the mineralization of organic compounds [27].

The composting process depends on the combinations of composting mass and its relevant ratios, i.e., the carbon: nitrogen ( $\mathrm{C}: \mathrm{N})$ ratio and the presence or absence of inoculants. Suitable ratios for the combination of waste and inoculants are required to produce high-quality mature compost. The metabolic analysis of the composting process can help better understand the process parameters. The utilization of biological methods such asthe inoculation of selected microbial strains can provide high 
efficiency for waste management, as these microorganisms help speed up the particle decomposition process and reduce the composting process time [28].

\section{Aim Of Paper}

Due to controversial data on the efficiency of microbial inoculation and the need to improve the approach to the composting process, the aim of this study was to evaluate the efficiency of the new model of bioreactor with forced aeration system about the time of the material to be composted, the physicochemical dynamics of microorganisms and to study the cultivable microorganisms during the process of food waste composting for to later select starter cultures for the formulation of a possible cocktail of selected microorganisms to be used as compost accelerator, comparing the effectiveness of two inoculants (non-commercial $((\mathrm{NCl}))$ and commercial $((\mathrm{Cl})))$ in relation to the control treatment over time in the composting process.

\section{Methods}

\section{Step 1. Inoculum preparation}

The experiment was carried out using two different inoculants, one noncommercial $(\mathrm{NCl})$ and one commercial ( $\mathrm{Cl}$ - biological product made up of a mix of microorganisms, being basically lactic acid bacteria, with species not defined by the manufacturer, used for accelerating composting of organic solid waste from agricultural and household waste. According to the manufacturer, it promotes exponential increase in microbial activity, improving the fermentation and composting process by converting organic matter into nutrients such as acids and nitrogen compounds quickly and safely).

The noncommercial inoculum was prepared using $700 \mathrm{~g}$ of unsalted rice cooked - not to change the composition of rice, in distilled water (Fig. 1). After cooking, the rice was placed in a plastic tray covered with canvas, which was placed in the native forest on the Federal University of Lavras, during the spring, with mild temperatures. Soil litter was placed over the tray to collect the natural microbiota of the environment. The collection period was of 15 days.

Afterwards, rice with microbial growth was deposited into a 20 liters container, homogenized with 1 liter of sterile sugar cane juice, and then made to a total volume of 20 liters with distilled water. For 20 days the container was stored in a cool, ventilated and closed space [29].

The commercial inoculum was prepared according to the manufacturer's instructions in which the recommended amount of distilled water and sugar was added to the concentrated product, and after fermentation for 20 days at room temperature, the product was ready for use. Compost without the addition of inoculants was used as the control treatment. 


\section{Step 2. Preparation Of Compost Mixture}

Compost mixture was performed by mixing organic waste from the Lavras University Restaurant (RU) and garden waste. For the calculation of the proportion of organic residues and residues from the landscaping that were added to the composters, so that if the ideal $\mathrm{C} / \mathrm{N}$ ratio was reached for the start of composting, the initial characterization of the waste components was performed, described in the Table 1.

Table 1

Initial characterization of residues.

\begin{tabular}{|llll|}
\hline Material & Carbon & Nitrogen & Relation C/N \\
\hline Garden waste & 39 & 0,6 & $65 / 1$ \\
\hline Organic waste (RU) & 35,16 & 2,93 & $12 / 1$ \\
\hline *RU = University restaurant & & \\
\hline
\end{tabular}

The present work used a new type of bioreactor built with concrete blocks and an air injection system. The composters had $1 \mathrm{~m}^{3}(1 \mathrm{~m} \times 1 \mathrm{~m} \times 1 \mathrm{~m})$, with monitored temperature and aeration to ensure a minimum oxygen concentration of 10\% [30]. Temperature sensors were placed inside each compost (PT10 digital thermometer model MPT2, Lexitron-Guemisa, Madrid, Spain). Forced air (6.3 $\mathrm{m}^{3} / \mathrm{min}$ ) was supplied from the bottom of the pile through $5 \mathrm{~cm}$ diameter PVC tubing at the base of the composting cell, traversing the cell horizontally $10 \mathrm{~cm}$ from the rear edge, with $1 \mathrm{~cm}$ holes in diameter, in 3 points of the tube $(25 \mathrm{~cm}, 50 \mathrm{~cm}$ and $75 \mathrm{~cm}$ ), connected to a Ventibras air injection pump, with 5 horse axial fan, for 30 minutes every 3 days (Supplementary material, Fig. S1).

The mixture was characterized physicochemical before the addition of the inoculum and the beginning of the fermentation process with a C:N ratio (30:1) and a moisture content of approximately 50 to $60 \%$ of the field capacity. The height of the compost piles was monitored during sampling with a tape measure to monitor the compaction of the material and the decomposition of the particles.

All waste was crushed into small particles with the help of a crusher. The organic wastes from the UR were added directly to the garden waste at a ratio of 1:2.5 in each of the composters and mixed with the help of a tractor, resulting in a homogeneous mixture. Immediately after, the starter cultures were inoculated with direct applications of the reactivated inoculum on the mixture of residues. In the initial time, 5 liters of inoculum (both $\mathrm{NCl}$ and $\mathrm{Cl}$ ) plus 15 liters of water were used in each compost, except the compost with the control treatment.

Moisture content was controlled by the hand test consisting of "moistening and rubbing a little of the compost between the palms", if the compost is ready, it will not get dirty, loosening easily, and kept between $50 \%$ and $60 \%$, and irrigations are performed when necessary according to this standard throughout the composting process to maintain the ideal moisture content [31]. Irrigations were 
performed on average every 3 days, with an average amount of 10 liters of water per compost each time [32].

The samples were collected in triplicate throughout the composting process. In the initial time were collected 3 samples of 1 to $10 \mathrm{~cm}, 3$ samples of $45 \mathrm{~cm}$ and 3 samples of $90 \mathrm{~cm}$, respectively. The sampling depth has changed throughout the process due to the reduction in the height of the piles, always maintaining the collection on the surface, interior and bottom of the pile. Surface, interior and bottom composting samples were homogeneously mixed for analysis and after 0,60 and 120 days for the analysis of the physical and chemical dynamics. Samples were taken after $0,5,10,20,40,60$ and 120 days for the quantification of the microorganisms.

\section{Step 3. Physicochemical Analyses}

The physicochemical analyzes were performed during times $0 ; 60$ and 120 days of composting. The moisture content was evaluated by drying at $105^{\circ} \mathrm{C}$ until having the same weight with 3 readings followed. The lowering of the piles was measured using tape measure to follow the lodging of the material and the decomposition of the particles. The fertility of the composting were determined according to the Manual of Soil Analysis [33]. The following parameters were evaluated: $\mathrm{C} ; \mathrm{N} ; \mathrm{C}: \mathrm{N} ; \mathrm{H}+\mathrm{Al}$ (potential acidity); $\mathrm{pH}$ in $\mathrm{H}_{2} \mathrm{O}$; P-rem (remaining phosphorus); $\mathrm{P}$ available; $\mathrm{K} ; \mathrm{SO}_{4}$; $\mathrm{Na}$; $\mathrm{Ca}$; $\mathrm{Mg} ; \mathrm{S}$; $\mathrm{B}$; $\mathrm{Cu} ; \mathrm{Fe}$; $\mathrm{Mn}$; Zn; organic matter (OM); organic carbon (OC); V (base saturation); m (aluminum saturation); SB (sum of bases); total CEC (cations exchange capacity) and effective CTC (Embrapa, 2011). The micronutrients were quantified using the Mehlich method [34].

\section{Step 4. Microbiological Analyses}

Microbial counting of cultivable microorganisms was carried out from inoculum and samples at intervals, $0 ; 5 ; 10 ; 20 ; 40 ; 60$ and 120 days in triplicate. $25 \mathrm{~g}$ of each sample was added to $225 \mathrm{~mL}$ of sterile peptone water in a shaker at 120 revolutions per minute (rpm) for $30 \mathrm{~min}$ at room temperature [35]. The samples were mixed in a stomacher at normal speed for $60 \mathrm{~s}$, and 10-fold dilutions were prepared.

Seven different types of culture media were used to study the microbial communities. Nutrient Agar (NA, Merck) was used as a general medium for the viable mesophilic bacteria population [36]. GYC (50 g glucose, $10 \mathrm{~g}$ yeast extract, $5 \mathrm{~g} \mathrm{CaCO}_{3}$ and $20 \mathrm{~g}$ agar) for acetic acid bacteria according [37]. MRS (De Man Rogosa Sharpe, Merck) agar containing $0.1 \%$ cysteine - $\mathrm{HCl}$ was used for Lactic acid bacteria growth under anaerobic conditions according [36]. MRS plates were incubated in acrylic anaerobic jars. After spreading, the plates were incubated at 28 for $48 \mathrm{~h}$. The counting and isolation of actinobacteria were performed using Aaronson medium ( $2 \mathrm{~g} \mathrm{KNO}_{3}, 0.8 \mathrm{~g}$ casein, $2 \mathrm{~g} \mathrm{NaCl}^{2} 2 \mathrm{~g} \mathrm{~K}_{2} \mathrm{HPO}_{4}, 50 \mathrm{mg} \mathrm{MgSO}$.7 $7 \mathrm{H} 2 \mathrm{O}$, $20 \mathrm{mg} \mathrm{CaCO}_{3}, 40 \mathrm{mg} \mathrm{FeSO}_{4} .7 \mathrm{H} 2 \mathrm{O}, 15 \mathrm{~g}$ agar), incubated at $45^{\circ} \mathrm{C}$ for 72 to $120 \mathrm{~h}$ [38]. The counting and isolation of yeasts were performed using YEPG $(10 \mathrm{~g}$ yeast extract, $10 \mathrm{~g}$ bacteriological peptone, $20 \mathrm{~g}$ glucose, $20 \mathrm{~g}$ agar with $\mathrm{pH} 3.5$ ) and incubated at $28^{\circ} \mathrm{C}$ for $48 \mathrm{~h}$ [39]. The filamentous fungi population 
was counting using PDA (200 g raw potatoes, $20 \mathrm{~g}$ dextrose, $20 \mathrm{~g}$ agar, $1 \mathrm{~L}$ distilled water) and incubated at $25^{\circ} \mathrm{C}$ for 7 days [40].

The morphological characteristics of the colonies (cell size, cell shape, edge, color, and brightness) were recorded and the square root of the number of colonies counted for each morphotype was purified by streaking on new agar plates [41].

The phenotypic characterization of the bacterial colonies was performed using Gram staining, catalase and oxidase activities and motility tests [42]. The pure cultures were stored in an ultra-freezer at $-80{ }^{\circ} \mathrm{C}$ in the same broth culture media used for plating, containing $20 \%$ glycerol $(w / w)$. Yeast colonies were characterized for morphology and biochemical assessments as described by [43]. Filamentous fungi were observed with an optical microscope for preliminary identification. This was done by morphotype analysis of the colony, especially color and appearance using the proposals of Pitt and Hocking, 1997.

\section{Step 5. Experimental Design}

The composting process consisted of three treatments: control (without inoculation), noncommercial inoculum $(\mathrm{NCl})$ and commercial inoculum $(\mathrm{Cl})$, with 6 replicates, totaling 18 composters. The composters were distributed in a completely randomized design (CRD) in the parcel scheme subdivided in time. The data obtained during the composting process (chemical and microbiological parameters) were analyzed using the statistical software Sisvar and the principal components analysis using the STATISTICA 7.0 software.

\section{Results}

\section{Step 1. Evolution of temperature}

During the bio-oxidative phase, a maximum temperature of $65^{\circ} \mathrm{C}$ was reached for all treatments. High temperatures (thermophiles) $\left(>50^{\circ} \mathrm{C}\right)$ may be related to the gradual degradation of easily biodegradable material in the bio-oxidative phase, which produces a lot of energy, increased sharply the temperature [45].

\section{Step 2. Physical and chemical dynamics}

The physicochemical changes during the composting process are shown in Table 2 and Figure 3.

There was a tendency for humidity to decrease over time and between treatments. However, the variable moisture presented a fall, but not a constant, over time.

Table 2. Physical and chemical parameters during composting for Control, Efficient microorganisms and commercial inoculum treatments. 


\begin{tabular}{|c|c|c|c|c|c|c|c|c|c|}
\hline \multirow[t]{3}{*}{ Treatment } & \multicolumn{3}{|c|}{ Control } & \multicolumn{3}{|c|}{ Efficient microorganisms } & \multicolumn{3}{|c|}{ Commercial inoculum } \\
\hline & \multicolumn{9}{|c|}{ Time (days) } \\
\hline & $\overline{0}$ & 60 & 120 & 0 & 60 & 120 & 0 & 60 & 120 \\
\hline $\mathrm{C}$ & 21.6 & 20.2 & 19.1 & 21.8 & 19.1 & 13.6 & 24.5 & 15.4 & 14.2 \\
\hline $\mathrm{N}$ & 0.9 & 0.9 & 0.9 & 1.2 & 1.2 & 1.2 & 1.2 & 1.2 & 1.2 \\
\hline $\mathrm{C}: \mathrm{N}$ & 24.1:1 & $16.8: 1$ & 15.9:1 & $24.2: 1$ & 15.9:1 & $11.3: 1$ & $27.2: 1$ & $12.8: 1$ & $11.8: 1$ \\
\hline Humidity & 43.3 & 28.8 & 26.5 & 39.3 & 26,00 & 35.9 & 41.5 & 25.9 & 31.4 \\
\hline Pile Hight & 100.00 & 58.6 & 53.00 & 100.00 & 58.4 & 51.4 & 100.00 & 63.00 & 50.6 \\
\hline $\mathrm{Al}$ & 0.1 & 0.1 & 0.1 & 0.1 & 0.1 & 0.1 & 0.1 & 0.1 & 0.1 \\
\hline $\mathrm{H}+\mathrm{Al}$ & 3.2 & 0.8 & 0.8 & 3.5 & 0.7 & 0.9 & 5.2 & 0.8 & 0.8 \\
\hline $\mathrm{pH} \mathrm{H}_{2} \mathrm{O}$ & 6.3 & 8.4 & 8.1 & 5.9 & 8.5 & 8,00 & 5.6 & 8.3 & 8.1 \\
\hline P rem & 55.4 & 52.00 & 54.5 & 56.4 & 48.7 & 55.3 & 52.00 & 57.1 & 53.9 \\
\hline $\mathrm{P}$ available & 379.2 & 394.1 & 423.2 & 245.4 & 257.6 & 545.9 & 292.00 & 318.2 & 577.4 \\
\hline $\mathrm{K}$ & 15.3 & 16.7 & 15.5 & 11.7 & 16.5 & 12.3 & 10.6 & 16.4 & 13.4 \\
\hline $\mathrm{SO}_{4}$ & 456.2 & 74.9 & 119.2 & 360.7 & 63.1 & 127.00 & 302.4 & 113.8 & 93.5 \\
\hline $\mathrm{Na}$ & 224.6 & 250.00 & 192.3 & 303.7 & 202.8 & 224.1 & 399.9 & 237.5 & 208.5 \\
\hline $\mathrm{Ca}$ & 12.00 & 7.5 & 12.1 & 10.5 & 10.2 & 10.3 & 7.9 & 8.2 & 9.3 \\
\hline $\mathrm{Mg}$ & 4.00 & 2.8 & 4.2 & 3.5 & 3.4 & 3.4 & 2.9 & 3.2 & 3.2 \\
\hline S & 152.1 & 25.00 & 39.7 & 120.3 & 21.00 & 42.3 & 100.8 & 37.9 & 31.2 \\
\hline B & 2.7 & 1.3 & 2.7 & 1.9 & 1.3 & 1.3 & 1.8 & 1.7 & 1.4 \\
\hline $\mathrm{Cu}$ & 2.2 & 0.9 & 0.9 & 2.00 & 0.8 & 0.8 & 2.1 & 1.2 & 1 \\
\hline $\mathrm{Fe}$ & 69.9 & 28.3 & 26.3 & 49.1 & 21.5 & 25.9 & 37.4 & 31.8 & 27.3 \\
\hline $\mathrm{Mn}$ & 87.5 & 94.7 & 94.00 & 61.6 & 99.6 & 80.6 & 44.2 & 85.8 & 84.2 \\
\hline $\mathrm{Zn}$ & 9.7 & 11.7 & 12.3 & 7.1 & 12.2 & 13.4 & 10.7 & 11.2 & 14.00 \\
\hline M.O & 29.00 & 15.2 & 19.1 & 21.8 & 19.1 & 13.6 & 24.5 & 15.4 & 14.2 \\
\hline C.O & 16.8 & 8.8 & 11.1 & 12.7 & 11.1 & 7.9 & 14.2 & 9.00 & 8.2 \\
\hline $\mathrm{V}$ & 91.0 & 97.3 & 97.5 & 88.4 & 98.0 & 96.9 & 81.7 & 97.4 & 97.2 \\
\hline M & 0.4 & 0.2 & 0.2 & 0.5 & 0.2 & 0.2 & 0.4 & 0.3 & 0.3 \\
\hline SB & 32.3 & 28.1 & 32.7 & 27.1 & 31.1 & 26.9 & 23.1 & 28.8 & 26.8 \\
\hline Total CTC & 35.5 & 28.9 & 33.5 & 30.6 & 31.7 & 27.7 & 28.3 & 29.6 & 27.6 \\
\hline Effective CTC & 32.4 & 28.2 & 32.7 & 27.2 & 31.1 & 26.9 & 23.2 & 28.9 & 26.8 \\
\hline
\end{tabular}

Reduction/lowering of pile hight measurement was measured in $\mathrm{cm}$.

$\mathrm{Al} ; \mathrm{H}+\mathrm{Al} ; \mathrm{K}, \mathrm{Na} ; \mathrm{Ca} ; \mathrm{Mg} ; \mathrm{SB}$; total CTC and effective CTC were measured in $\mathrm{cmol} / \mathrm{dm}^{3}$. 
The $\mathrm{C}: \mathrm{N}$ ratio for $\mathrm{NCl}$ and $\mathrm{Cl}$ compost samples decreased significantly with time and started stabilized after 60 days in $\mathrm{NCl}$ treatment (12.8) and 120 days in $\mathrm{Cl}$ treatment (15.9). However, both samples showed C:N below 12 (11.8 and 11.3, respectively), and this rate indicated a direct mineralization of organic nitrogen [51]. Control showed C:N equal to 15.9 at the end of the composting process. It means that the process of composting without inoculum could not finished at 120 days. $\mathrm{C}$ : $\mathrm{N}$ ratio decreased as the degradation process proceeded (especially in $\mathrm{NCl}$ and $\mathrm{Cl}$ ) and $\mathrm{C}$ valorized mainly as carbon dioxide [52].

In general, the variables sodium, total acidity, base saturation index, copper, manganese and ion exchange capacity were the variables that most contributed to explain the variability of the data. The organic matter contents presented initial values of $29.0 \%, 21.8 \%$ and $24.5 \%$ and final values of $19.1 \%$, $13.6 \%$ and $14.2 \%$, showing decrease of $9.9 \% .8 .2 \%$ and $10.3 \%$ in the control, MS and IC treatments, respectively, throughout the process. In relation to the macronutrients, available phosphorus levels increased during the composting process, reaching $423.3 \mathrm{mg} / \mathrm{dm}^{3}, 545.9 \mathrm{mg} / \mathrm{dm}^{3}$ and $577.4 \mathrm{mg} / \mathrm{dm}^{3}$ in the control, $\mathrm{NCl}$ and $\mathrm{Cl}$ treatments, respectively. The initial values of $\mathrm{K}$ in the control, $\mathrm{NCl}$ and $\mathrm{Cl}$ treatments were $15.3 \mathrm{cmol} / \mathrm{dm}^{3}, 11.7 \mathrm{cmol} / \mathrm{dm}^{3}$ and $10.6 \mathrm{cmol} / \mathrm{dm}^{3}$, while the final values were slightly higher, with $15.5 \mathrm{cmol} / \mathrm{dm}^{3}, 12.3 \mathrm{cmol} / \mathrm{dm}^{3}$ and $13.4 \mathrm{cmol} / \mathrm{dm}^{3}$. The Ca values remained constant, with an initial mean of $12.1 \mathrm{cmol} / \mathrm{dm}^{3}$ and a final average of $10.5 \mathrm{cmol} / \mathrm{dm}^{3}$. The $\mathrm{Mg}$ values increased with a change from $3.4 \mathrm{cmol} / \mathrm{dm}^{3}$ to $3.6 \mathrm{cmol} / \mathrm{dm}^{3}$. The opposite occurred with the values of $\mathrm{S}$ and $\mathrm{Na}$, which decreased in both treatments throughout the process.

As higher the decomposition rate, higher was the mineralization rate of some nutrients at the end of composting and higher was the quality of the biofertilizer [58]. In terms of micronutrients, only $\mathrm{Mn}$ and $\mathrm{Zn}$ showed a significant increase during composting.

The principal component analysis (PCA) of the physical and chemical parameters obtained during composting. In this analysis, the principal components (PC) 1 and 2 explained $66.19 \%$ of the data variance (Figure 3).

With the physiochemical variables analysis, there was a high relation with PC1, that demonstrated the influence of treatment $\mathrm{NCl}$ and $\mathrm{Cl}$ in results, only variables $\mathrm{Cu}, \mathrm{pH}$ and degradation of organic material showed low relation with the $\mathrm{PC1}$. In relation at $\mathrm{PC} 2$ the influence of $\mathrm{Cl}$ treatment that showed high influence for $\mathrm{Ca}, \mathrm{Mg}$, lowering, $\mathrm{Na}, \mathrm{P}-\mathrm{rem}, \mathrm{B}, \mathrm{S}$. C, pH and M.O available, already $\mathrm{NCl}$ showed influence for $\mathrm{Cu}$ and $\mathrm{H}+\mathrm{Al}$ values (Figure 3 ).

\section{Step 3. Microbial communities}

The yeast population in the $\mathrm{NCl}$ inoculum was $5.5 \log \mathrm{CFU} \mathrm{g-1}$, lower than the $\mathrm{Cl}$ inoculum yeast count of $8.0 \log$ CFU g-1.

The aerobic mesophilic and thermophilic bacterial population remained stable during the composting process, with approximately $8.0 \log$ CFU g- 1 of compost, even in the thermophilic phase (T5 and T10) in 
both treatments (Figures $4 \mathrm{a}, \mathrm{b}$ and $\mathrm{c}$ ).

The population of actinobacteria remained constant only in the $\mathrm{Cl}$ treatment (Figure 4c)), whereas in the control (Figure 4b)) and $\mathrm{NCl}$ (Figure a)) treatments there was a decrease in the population in the thermophilic phase (T5 and T10). The yeast population varied throughout composting time, showing similar behavior in all treatments (Figures $\mathrm{a}, \mathrm{b}$ and $\mathrm{c}$ ), with a lower population compared to bacteria and actinobacteria, remained stable in the first 20 days of composting, but after 40 days of composting showed no growth. The population of filamentous fungi remained stable, over time, in all treatments (Figures $\mathrm{a}, \mathrm{b}$ and $\mathrm{c}$ ), with approximately $5.0 \log _{\mathrm{CFU}} \mathrm{g}^{-1}$ of compound.

\section{Discussion}

\section{Step 1. Evolution of temperature}

Temperature is one of the main parameters used to monitor the composting process and determine the decomposition rate of organic matter [7]. The thermal profile of the compost (Fig. 2) allowed to distinguish two phases: bio-oxidative (40 days) and maturation phase (80 days) independent on the treatment, totalling 120 days of composting, which can be considered a viable process, since other authors such as Jurado et al. (2014) [44], totaled the process at 189 days of composting. Regardless of time, the composting process is advantageous because it happens the recycling of materials that could be polluting or cause public health problems.

The temperature profile showed rapid increase, reaching $60^{\circ} \mathrm{C}$ during the first day. These results indicated that there was a satisfactory nutrient balance $[28,46]$. The thermophilic phase is important to annihilate the potential pathogen, weed and sanitizing the compost [35]. The composting process has to maintain at a thermophilic temperature of a minimum of three consecutive days to inactivated the pathogen growth [47].

In the present study, the 3 treatments followed this trend, but $\mathrm{NCl}$ and control maintained an average $5^{\circ} \mathrm{C}$ higher than $\mathrm{Cl}$. The end of the bio-oxidative phase exhibited fluctuations in temperature and was followed by a cooling phase at which point the temperature was approximately $40^{\circ} \mathrm{C}$ (Fig. 2), which is characteristic of a stable mesophilic phase [5].

The temperature profiles for the composting process with $\mathrm{NCl}, \mathrm{Cl}$ and control treatment showed similar trend (Fig. 2). Temperature increased dramatically within the first few days of the composting process and decreased gradually after reaching the peak around 15-18 days. Increased temperature is caused by heat generation from the microbial metabolism by the respiration and decomposition of the substrate. Therefore, this profile might be significantly affected by microbial inoculum if the input material does not have sufficient microbial population for the degradation process [28]. The control and $\mathrm{NCl}$ treatments presented approximately 5 to $7^{\circ} \mathrm{C}$ higher than the $\mathrm{Cl}$ throughout the composting process, resulting in the stabilization of this compost several days in advance. 


\section{Step 2. Physical and chemical dynamics}

Aeration is one of the key parameters in controlling the activities of the waste being composted, as it influences the temperature, moisture and $\mathrm{O}_{2}$ supply to the microorganisms. In the composting process, the predominant microorganisms are aerobic, therefore, they need oxygen to survive and maintain their metabolism [48]. The oxygen present in composting also removes excess moisture from the composting mass, avoiding the need for higher temperatures [49].

The process of assimilation of nutrients by microorganisms occurs through their cell walls, so that the metabolic activities organic matter degradation can occur, it is necessary that the humidity of the medium is adequate [49]. Despite periodic moistening, humidity did not always remain around $50 \%$ to $60 \%$ which was ideal, but around $40 \%$. According to [46], mixtures of residues that have low moisture (under $50 \%$ ) content inhibit microbial activity, because in any other biological process, water is essential for metabolism. However, by means of periodic moistenings, a value was guaranteed that did not restrict biological activities.

The reduction in height of the compost pile can be indicative of process evolution due to the decomposition of the parent material into smaller particles, which implies the reduction of the porosity of the pile.

One goal of the present study, which used garden waste and restaurant waste, was to assess the composting substrates, including the adjustment of the $\mathrm{C} / \mathrm{N}$ ratio and any increases in the availability of nutrients. Karadag et al. (2013) [50] observed that carbon and nitrogen used by microorganisms for energy and growth resulted in changes in the $\mathrm{C} / \mathrm{N}$ ratio during the composting process. During the composting process, organic matter degradation resulted in carbon reduction, which decreased at the end of composting (Table 2).

The variation of total acidity and $\mathrm{pH}$ value is a result of organic acids production by microbial metabolism [53]. The increase in pH value and the decrease in the exchangeable acidity (H+Al) (Table 2) are characteristics of a mature compost and resulted in increased degradation of organic acids and amino acids, which provides additional nutrients $[54,55]$. The $\mathrm{pH}$ values in all treatments turned from acidic to a range of neutral and weakly alkaline indicating the stability of organic matter. The $\mathrm{pH}$ value at the first weeks was acidic $(5.6-6.3)$ (Table 2). It gradually turned basic $(8.0-8.1)$ due to the releases of ammonia (Table 2) [24] and conversion of organic acid into $\mathrm{CO}_{2}$ by microbial activity [56].

The increase in $\mathrm{P}$ availability during composting may be related to organic matter degradation, increase in $\mathrm{pH}$ and decrease in Fe content in all treatments (Table 2), and also the activity of phosphatase, which is produced by phosphate-solubilizing microorganisms [57].

The nutrients are not volatile, therefore, the increase in the total content of $\mathrm{P}$ and $\mathrm{K}$, for example, was mainly due to the loss of compost mass due to the biodegradation of organic content, that is, the content of these nutrients increases the metabolic activity of the microorganisms during composting and thus 
increases the organic waste decomposition process [59]. This showed that the increase of the contents of these elements in both treatments, indicated a satisfactory rate of decomposition, in spite of the decrease in the contents of some nutrients, which were not significant.

Regarding the physical and chemical characteristics of the composting process, it was observed that the inoculation of the non-commercial and the commercial inoculum did not significantly differentiate from the natural composting process (Table 2).

These results of PCA showed the clear influence of the inoculation treatments in relation the control treatment, with better efficiency of $\mathrm{Cl}$ in relation at the $\mathrm{NCl}$ treatment (Figure 3).

Fan et al. (2018) [28] noted that factors such as the humification process, fat reduction and $\mathrm{N}$ content are altered when non-commercial inoculum are inoculated into the composting process. Studies on the suitability of different inoculants are still inconclusive, likely due to the complexity of the composting process and the nature of organic wastes [2]. Studies by [60] have demonstrated that inoculation using a mature compost may be more indicative than the inoculation of starter cultures in the composting process, as there was no significant effect on the composting time and quality of the final compost. Likewise, [61] reported that inoculation with lignocellulosic microbiota was not effective in kitchen waste composting when compared to control treatments.

\section{Step 3. Microbial communities}

Compost maturity is reached when microbiological decomposition is complete and is accompanied by the mineralization of the components, making them available to the plants, and improving the physical, chemical and biological properties of the soil [62]. According to [46], mixtures of waste with low moisture content inhibit microbial activity. However, periodic irrigation ensured a moisture content that did not limit the microbial population in different treatments (Figure 4).

During all process of composting, in both of treatments, the population of prokaryotes (bacteria and actinobacteria) was higher than that of eukaryotes (fungi and yeasts), as also observed by [35]. Even the beginning of the bio-oxidative phase presenting high temperatures $\left(>50^{\circ} \mathrm{C}\right)$, thermotolerant mesophilic microorganisms are able to withstand this treatment [63]. Even when there is no change in the total plate count of microorganisms, there may be a reduction in diversity indices, which may favor certain microbial groups [64].

The inoculation of the $\mathrm{NCl}$ and $\mathrm{Cl}$ did not influence the composting process. Microbial communities were similar throughout the process in both treatments. In composts without the addition of starter cultures, several changes naturally occur in the physical and chemical structure, because the microorganisms present are capable of biological activity to increase the temperature $\left(55-70^{\circ} \mathrm{C}\right)$, which provides the dominance of thermophilic microorganisms with high degradability of organic matter [45]. Thus, the endogenous populations of microorganisms adapt to environmental variations provided by the

Page 12/22 
composting process and plays an important role in the degradation of organic matter, mineralization of nutrients, control of pathogens, and stabilization of the compost $[45,64]$.

\section{Conclusions}

The new type of bioreactor shown to be efficient and helped accelerate decomposition of composted material. The analysis of organic matter transformation during the composting of organic wastes showed complex physical, chemical and microbiological interactions. The treatments with the $\mathrm{NCl}$ and $\mathrm{Cl}$ inoculum presented advantages in terms of the quality of the final product in comparison to the control treatment. During the composting process, in both treatments, there was a greater mineralization of $\mathrm{P}$ available and micronutrients as $\mathrm{Mn}$ and $\mathrm{Zn}$, which indicates that the compound can be used as a biofertilizer, however requiring additional tests and studies.

Although not the objective of this work, microbiome studies are needed as a tool to better understand the role of microorganisms in nutrient cycling in the compost.

\section{Declarations}

\section{Ethics approval and consent to participate}

Not applicable

\section{Consent for publication}

Not applicable

\section{Availability of data and materials}

The datasets used and/or analysed during the current study are available from the corresponding author on reasonable request.

\section{Competing interests}

The authors declared no potential conflicts of interest with respect to the research, authorship, and/or publication of this article.

\section{Funding}

The authors thanks Capes, CNPq and FAPEMIG for financial supports; to the Federal University of Lavras (UFLA) for the structure provided to accomplishment the experiments and to the technical support of the teachers.

\section{Authors' contributions}


SSG contributed to setting up and conducting the experiment, laboratory analysis, data analysis and article writing. LLRA and CAC contributed to the assembly and conduct of the experiment and laboratory analysis. GMR, RFS and JDRS contributed to data analysis and article writing.

\section{Acknowledgements}

Not applicable

\section{References}

1. Bao N, Thi D, Kumar G, Lin C-Y (2015) An overview of food waste management in developing countries: Current status and future perspective. J Environ Manage 157:220-229. https://doi.org/10.1016/j.jenvman.2015.04.022

2. Cerda A, Artola A, Font $X$ et al (2018) Composting of food wastes: Status and challenges. Bioresour Technol 248:57-67. https://doi.org/10.1016/j.biortech.2017.06.133

3. Ngoc Q, Tran M, Mimoto H, Nakasaki K (2015) Inoculation of lactic acid bacterium accelerates organic matter degradation during composting. Int Biodeterior Biodegradation 104:377-383. https://doi.org/10.1016/j.ibiod.2015.07.007

4. Zhao H-Y, Li J, Liu J-J et al (2013) Microbial Community Dynamics During Biogas Slurry and Cow Manure Compost. J Integr Agric 12:1087-1097. https://doi.org/10.1016/S2095-3119(13)60328-7

5. Huang Y-L, Sun Z-Y, Zhong X-Z et al (2017) Aerobic composting of digested residue eluted from dry methane fermentation to develop a zero-emission process. Waste Manag 61:206-212. https://doi.org/10.1016/j.wasman.2017.01.007

6. Zhang L, Sun X (2014) Changes in physical, chemical, and microbiological properties during the twostage co-composting of green waste with spent mushroom compost and biochar. Bioresour Technol 171:274-284. https://doi.org/10.1016/j.biortech.2014.08.079

7. Ren G, Xu • Xiuhong, Qu J et al (2016) Evaluation of microbial population dynamics in the cocomposting of cow manure and rice straw using high throughput sequencing analysis. Microb Biotechnol 32-101. https://doi.org/10.1007/s11274-016-2059-7

8. Sharma D, Yadav KD, Kumar S (2018) Biotransformation of flower waste composting: Optimization of waste combinations using response surface methodology. Bioresour Technol 270:198-207. https://doi.org/10.1016/j.biortech.2018.09.036

9. Li Z, Lu H, Ren L, He L (2013) Experimental and modeling approaches for food waste composting: A review. Chemosphere 93:1247-1257. https://doi.org/10.1016/j.chemosphere.2013.06.064

10. Deus RM, Battistelle RAG, Silva GHR (2017) Scenario evaluation for the management of household solid waste in small Brazilian municipalities. Clean Technol Environ Policy 19:205-214. https://doi.org/10.1007/s10098-016-1205-0

11. Zhang L, Sun X (2018) Effects of bean dregs and crab shell powder additives on the composting of green waste. Bioresour Technol J 260:283-293. https://doi.org/10.1016/j.biortech.2018.03.126 
12. Abdolali A, Guo WS, Ngo HH et al (2014) Bioresource Technology Typical lignocellulosic wastes and by-products for biosorption process in water and wastewater treatment: A critical review. Bioresour Technol 160:57-66. https://doi.org/10.1016/j.biortech.2013.12.037

13. Bueno P, Yañez R, Rivera A, Díaz MJ (2009) Modelling of parameters for optimization of maturity in composting trimming residues. Bioresour Technol 100:5859-5864. https://doi.org/10.1016/j.biortech.2009.06.042

14. Li S, Li D, Li J et al (2017) Evaluation of humic substances during co-composting of sewage sludge and corn stalk under different aeration rates. Bioresour Technol 245:1299-1302. https://doi.org/10.1016/j.biortech.2017.08.177

15. SANCHUKI CE (2011) Estudo da Compostagem Acelerada de Cama de Frango. Universidade Federal do Paran\&\#225

16. Külcü R, Yaldiz O (2014) The composting of agricultural wastes and the new parameter for the assessment of the process. Ecol Eng 69:220-225. https://doi.org/10.1016/J.ECOLENG.2014.03.097

17. Antunes LP, Martins LF, Pereira RV et al (2016) Microbial community structure and dynamics in thermophilic composting viewed through metagenomics and metatranscriptomics. Sci Rep 6:1-13. https://doi.org/10.1038/srep38915

18. Watteau F, Villemin G (2011) Characterization of organic matter microstructure dynamics during cocomposting of sewage sludge, barks and green waste. Bioresour Technol 102:9313-9317. https://doi.org/10.1016/j.biortech.2011.07.022

19. Bohacz J (2016) Lignocellulose-degrading enzymes, free-radical transformations during composting of lignocellulosic waste and biothermal phases in small-scale reactors. Sci Total Environ 580:744754. https://doi.org/10.1016/j.scitotenv.2016.12.021

20. Nakasaki K, Araya S, Mimoto H (2013) Inoculation of Pichia kudriavzevii RB1 degrades the organic acids present in raw compost material and accelerates composting. Bioresour Technol 144:521528. https://doi.org/10.1016/j.biortech.2013.07.005

21. Zhang $X$, Zhong $Y$, Yang $S$ et al (2014) Diversity and dynamics of the microbial community on decomposing wheat straw during mushroom compost production. Bioresour Technol 170:183-195. https://doi.org/10.1016/j.biortech.2014.07.093

22. Kinet R, Destain J, Hiligsmann S et al (2015) Thermophilic and cellulolytic consortium isolated from composting plants improves anaerobic digestion of cellulosic biomass: Toward a microbial resource management approach. Bioresour Technol 189:138-144.

https://doi.org/10.1016/j.biortech.2015.04.010

23. Onwosi CO, Igbokwe VC, Odimba JN et al (2017) Composting technology in waste stabilization: On the methods, challenges and future prospects. J Environ Manage 190:140-157. https://doi.org/10.1016/j.jenvman.2016.12.051

24. Pan IP, Sen SK (2013) Microbial and physico-chemical analysis of composting process of wheat straw. Indian J Biotechnol 12:120-128 
25. Lei F, Vandergheynst JS (2000) The effect of microbial inoculation and pH on microbial community structure changes during composting. Process Biochem 35:923-929.

https://doi.org/10.1016/S0032-9592(99)00155-7

26. Milinković M, Lalević B, Jovičić-Petrović J et al (2019) Biopotential of compost and compost products derived from horticultural waste-Effect on plant growth and plant pathogens' suppression. Process Saf Environ Prot 121:299-306. https://doi.org/10.1016/j.psep.2018.09.024

27. Zhang L, Sun X (2019) Changes in Physical, Chemical, and Microbiological Properties During the Two-Stage Composting of Green Waste due to the Addition of $\beta$-cyclodextrin. Compost Sci Util 27:46-60. https://doi.org/10.1080/1065657X.2019.1585304

28. Fan Y, Van, Jaromír J, Chew K et al (2018) Efficiency of microbial inoculation for a cleaner composting technology. 517-527. https://doi.org/10.1007/s10098-017-1439-5

29. Coutinho De Andrade M (2011) CADERNO DOS MICRORGANISMOS EFICIENTES (EM) Instruções práticas sobre uso ecológico e social do EM

30. Vargas-García MC, Suárez-Estrella F, López MJ, Moreno J (2010) Microbial population dynamics and enzyme activities in composting processes with different starting materials. Waste Manag 30:771778. https://doi.org/10.1016/j.wasman.2009.12.019

31. Schnnor $S$ Estudo de caso de compostagem de resíduos de podas urbanas e vermicompostagem de esterco bovino no Centro Estadual de Educação Profissional Manoel Moreira Pena. Faculdade União das Américas

32. Kiehl EJ (2004) Manual de compostagem: maturação e qualidade do composto. In: Manual de compostagem: maturação e qualidade do composto, $4^{\mathrm{a}}$ ed. Piracicaba, São Paulo, p 173

33. (2011) Documentos 1322 a edição revista Manual de Métodos de Análise de Solo Empresa Brasileira de Pesquisa Agropecuária Embrapa Solos Ministério da Agricultura, Pecuária e Abastecimento

34. Morales LA, Vázquez EV, Paz-Ferreiro J (2011) Influence of liming on the spatial and temporal variability of Mehlich-1 extractable Fe in a rice field. J Geochemical Explor 109:78-85. https://doi.org/10.1016/j.gexplo.2010.11.005

35. Lopez-Gonzalez JA, Lopez MJ, Vargas-Garcia MC et al (2013) Tracking organic matter and microbiota dynamics during the stages of lignocellulosic waste composting. Bioresour Technol 146:574-584. https://doi.org/10.1016/j.biortech.2013.07.122

36. Silva LCB (2010) IDENTIFICAÇÃO DE ACTINOBACTÉRIAS E Thermoactinomyces spp. ISOLADOS DO PROCESSO DE COMPOSTAGEM PARA A PRODUÇÃO DE Agaricus brasiliensis. 89

37. Oliveira DL, Wilbey RA, Grandison AS et al (2012) Separation of oligosaccharides from caprine milk whey, prior to prebiotic evaluation. Int Dairy J 24:102-106.

https://doi.org/10.1016/j.idairyj.2011.12.012

38. Dias BO, Silva CA, Higashikawa FS et al (2010) Use of biochar as bulking agent for the composting of poultry manure: Effect on organic matter degradation and humification. Bioresour Technol 101:1239-1246. https://doi.org/10.1016/j.biortech.2009.09.024 
39. Salama ES, Hwang JH, El-Dalatony MM et al (2018) Enhancement of microalgal growth and biocomponent-based transformations for improved biofuel recovery: A review. Bioresour Technol 258:365-375

40. Rempel A, Machado T, Treichel H et al (2018) Saccharification of Spirulina platensis biomass using free and immobilized amylolytic enzymes. Bioresour Technol 263:163-171. https://doi.org/10.1016/j.biortech.2018.04.114

41. Pereira JPC, Verheijen PJT, Straathof AJJ (2016) Growth inhibition of S. cerevisiae, B. subtilis, and E. coli by lignocellulosic and fermentation products. Appl Microbiol Biotechnol 100:9069-9080. https://doi.org/10.1007/s00253-016-7642-1

42. Tony Gutiérrez, Lonnie O. Ingram JFP (2006) Purification and characterization of a furfural reductase (FFR) from Escherichia coli strain LY01-an enzyme important in the detoxification of furfural during ethanol production. J Biotechnol 121:154-164. https://doi.org/10.1016/j.jbiotec.2005.07.003

43. Pereira Rodarte M, Ribeiro Dias D, Marques Vilela D, Freitas Schwan R (2011) Proteolytic activities of bacteria, yeasts and filamentous fungi isolated from coffee fruit (Coffea arabica L.). Acta Sci Agron Mar 457-464. https://doi.org/10.4025/actasciagron.v33i3.6734

44. Jurado MM, Suárez-Estrella F, Vargas-García MC et al (2014) Evolution of enzymatic activities and carbon fractions throughout composting of plant waste. J Environ Manage 133:355-364. https://doi.org/10.1016/j.jenvman.2013.12.020

45. Khalil Al, Hassouna MS, El-Ashqar HMA, Fawzi M (2011) Changes in physical, chemical and microbial parameters during the composting of municipal sewage sludge. World J Microbiol Biotechnol 27:2359-2369. https://doi.org/10.1007/s11274-011-0704-8

46. Bernardi FH (2011) Uso Do Processo De Compostagem No Aproveitamento De Resíduos De Incubatório E Outros De Origem Agroindustrial

47. Wichuk KM, McCartney D (2007) A review of the effectiveness of current time-temperature regulations on pathogen inactivation during composting. J Environ Eng Sci 6:573-586. https://doi.org/10.1139/S07-011

48. Jarboe LR, Liu P, Kautharapu KB, Ingram LO (2012) Optimization of enzyme parameters for fermentative production of biorenewable fuels and chemicals. Comput Struct Biotechnol J 3:e201210005. https://doi.org/10.5936/csbj.201210005

49. Duarte Gomes AP (2001) Fundamentos da compostagem de resíduos sólidos. Tesis Dr 1-333

50. Karadag D, Özkaya B, Ölmez E et al (2013) Profiling of bacterial community in a full-scale aerobic composting plant. Int Biodeterior Biodegradation 77:85-90. https://doi.org/10.1016/j.ibiod.2012.10.011

51. Margaritis M, Psarras K, Panaretou V et al (2018) Improvement of home composting process of food waste using different minerals. Waste Manag 73:87-100. https://doi.org/10.1016/j.wasman.2017.12.009

52. Hubbe MA, Nazhad M, Sánchez C (2010) Composting of lignocellulosics. BioResources 5:28082854 
53. Wei Y, Zhao Y, Shi M et al (2018) Effect of organic acids production and bacterial community on the possible mechanism of phosphorus solubilization during composting with enriched phosphatesolubilizing bacteria inoculation. Bioresour Technol 247:190-199.

https://doi.org/10.1016/j.biortech.2017.09.092

54. López-Cano I, Roig A, Cayuela ML et al (2016) Biochar improves $\mathrm{N}$ cycling during composting of olive mill wastes and sheep manure. Waste Manag 49:553-559.

https://doi.org/10.1016/j.wasman.2015.12.031

55. Makan A, Mountadar M (2012) Effect of $\mathrm{C} / \mathrm{N}$ ratio on the in-vessel composting under air pressure of organic fraction of municipal solid waste in Morocco. Waste Manag 14:241-249. https://doi.org/10.1007/s10163-012-0062-0

56. Iqbal H, Garcia-Perez M, Flury M (2015) Effect of biochar on leaching of organic carbon, nitrogen, and phosphorus from compost in bioretention systems. Sci Total Environ 521-522:37-45. https://doi.org/10.1016/j.scitotenv.2015.03.060

57. Busato JG, Lima LS, Aguiar NO et al (2012) Changes in labile phosphorus forms during maturation of vermicompost enriched with phosphorus-solubilizing and diazotrophic bacteria. Bioresour Technol 110:390-395. https://doi.org/10.1016/j.biortech.2012.01.126

58. Zhou Y, Selvam A, Wong JWC (2018) Chinese medicinal herbal residues as a bulking agent for food waste composting. Bioresour Technol 249:182-188. https://doi.org/10.1016/j.biortech.2017.09.212

59. Sudharsan Varma V, Yadav J, Das S, Kalamdhad AS (2015) Potential of waste carbide sludge addition on earthworm growth and organic matter degradation during vermicomposting of agricultural wastes. Ecol Eng 83:90-95. https://doi.org/10.1016/j.ecoleng.2015.05.050

60. Wang X, Pan S, Zhang Z et al (2017) Effects of the feeding ratio of food waste on fed-batch aerobic composting and its microbial community. Bioresour Technol 224:397-404. https://doi.org/10.1016/j.biortech.2016.11.076

61. Nair J, Okamitsu K (2010) Microbial inoculants for small scale composting of putrescible kitchen wastes. Waste Manag 30:977-982. https://doi.org/10.1016/j.wasman.2010.02.016

62. Gou C, Wang Y, Zhang X et al (2017) Inoculation with a psychrotrophic-thermophilic complex microbial agent accelerates onset and promotes maturity of dairy manure-rice straw composting under cold climate conditions. Bioresour Technol 243:339-346. https://doi.org/10.1016/j.biortech.2017.06.097

63. Liu L, Wang S, Guo X et al (2018) Succession and diversity of microorganisms and their association with physicochemical properties during green waste thermophilic composting. Waste Manag 73:101-112. https://doi.org/10.1016/j.wasman.2017.12.026

64. Huang Y, Li D, Wang L et al (2019) Decreased enzyme activities, ammonification rate and ammonifiers contribute to higher nitrogen retention in hyperthermophilic pretreatment composting. Bioresour Technol 272:521-528. https://doi.org/10.1016/j.biortech.2018.10.070

\section{Figures}




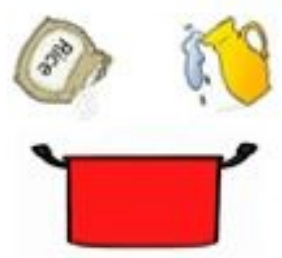

Add $700 \mathrm{~g}$ of rice and distilled water

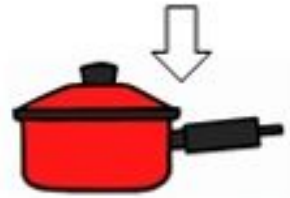

Cook for 15 minutes<smiles>C1C[C]2CCCC2C1</smiles>

Spread the rice over the pan<smiles>C1C[C]2CCCC2C1</smiles>

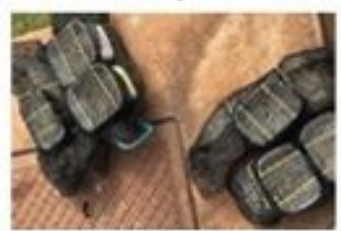

Palce the tray with the rice in place for collecting EMs

(A)

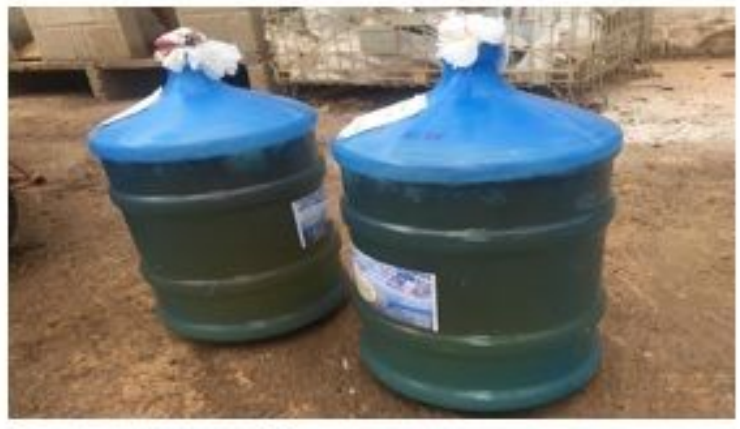

(C)

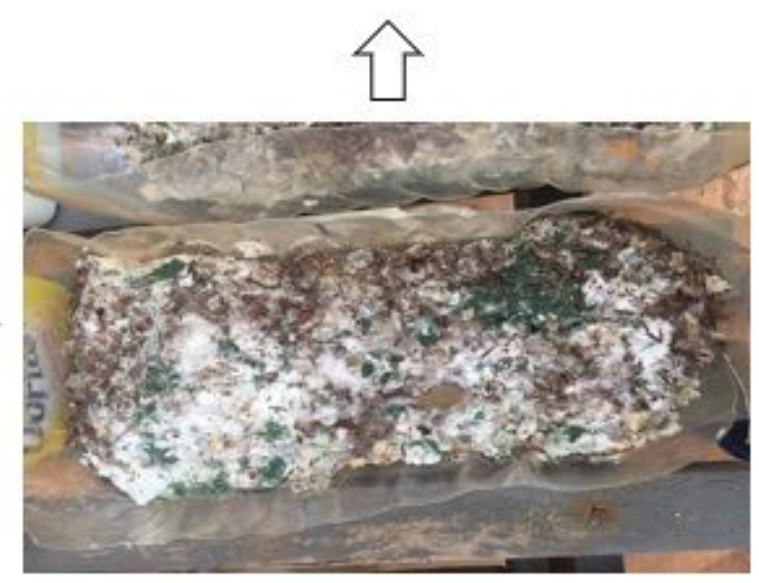

(B)

\section{Figure 1}

Process of obtaining and activating NCls. A - Procedures for capturing MS's; B - Aspect of the rice containing the $\mathrm{MS}$ before the activation; $\mathrm{C}$ - Activation of $\mathrm{NCl}$ in sugarcane juice [20] (with adaptations). 


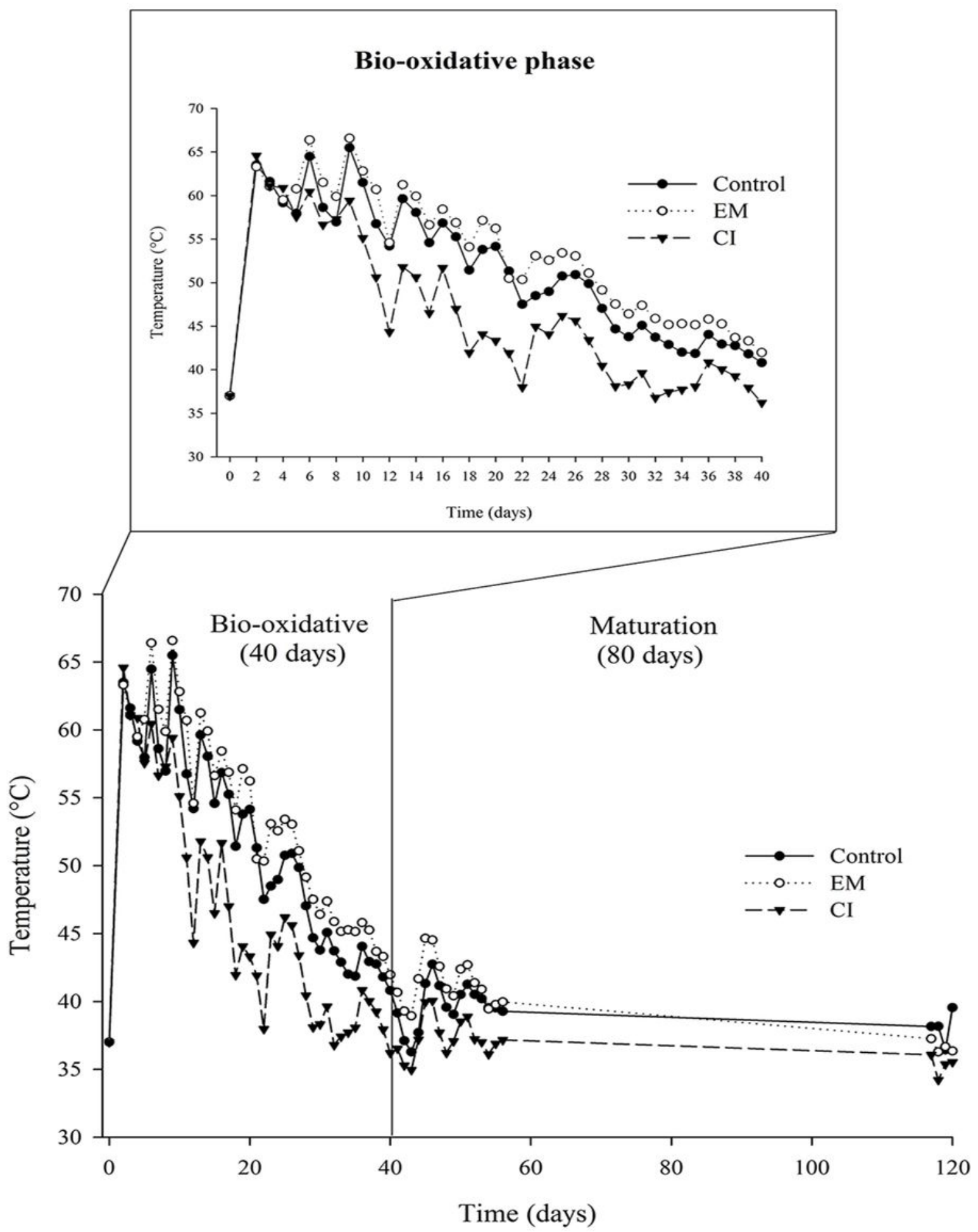

Figure 2

Thermal profile $\left(\mathrm{C}^{\circ}\right)$ of the three treatments Control; Efficient microorganisms $(\mathrm{NCl})$ and commercial inoculum $(\mathrm{Cl})$ during the composting process. 

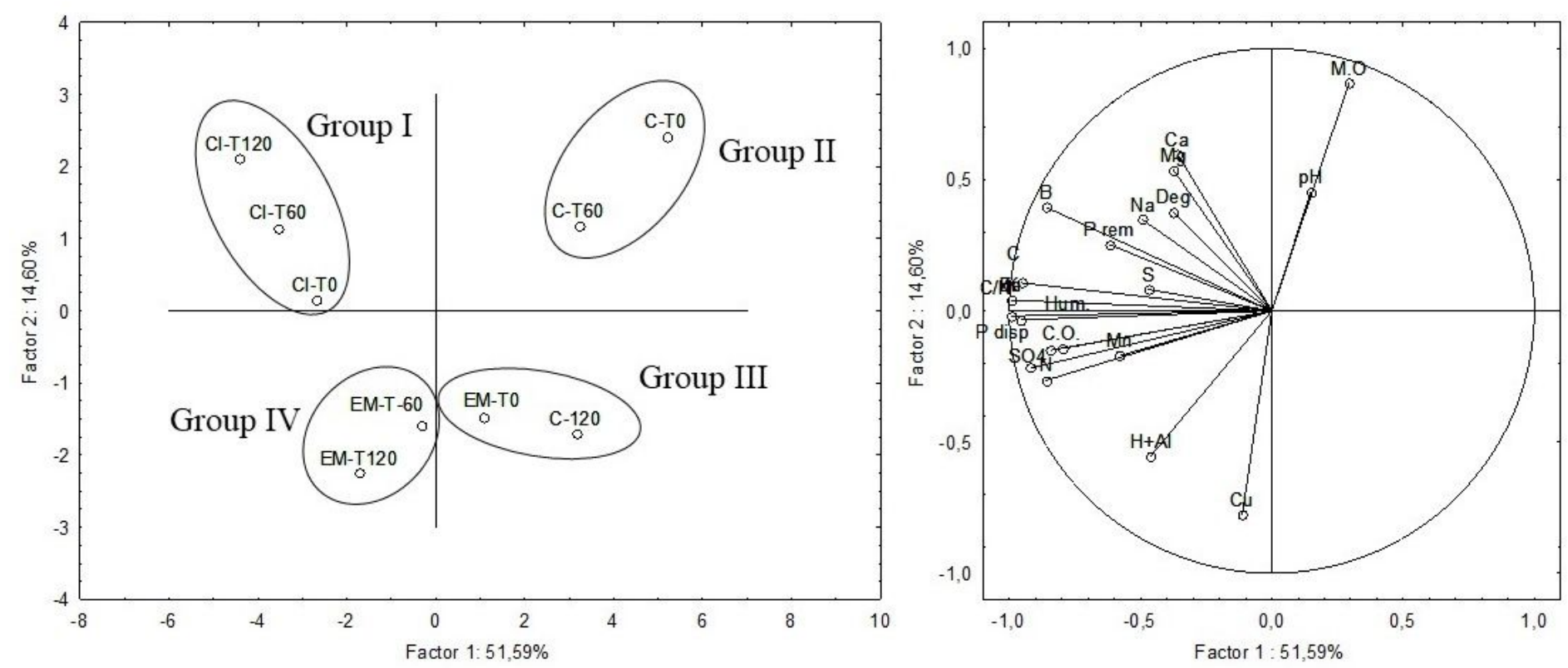

Figure 3

Analysis of major components of physical and chemical attributes during composting. 
a)

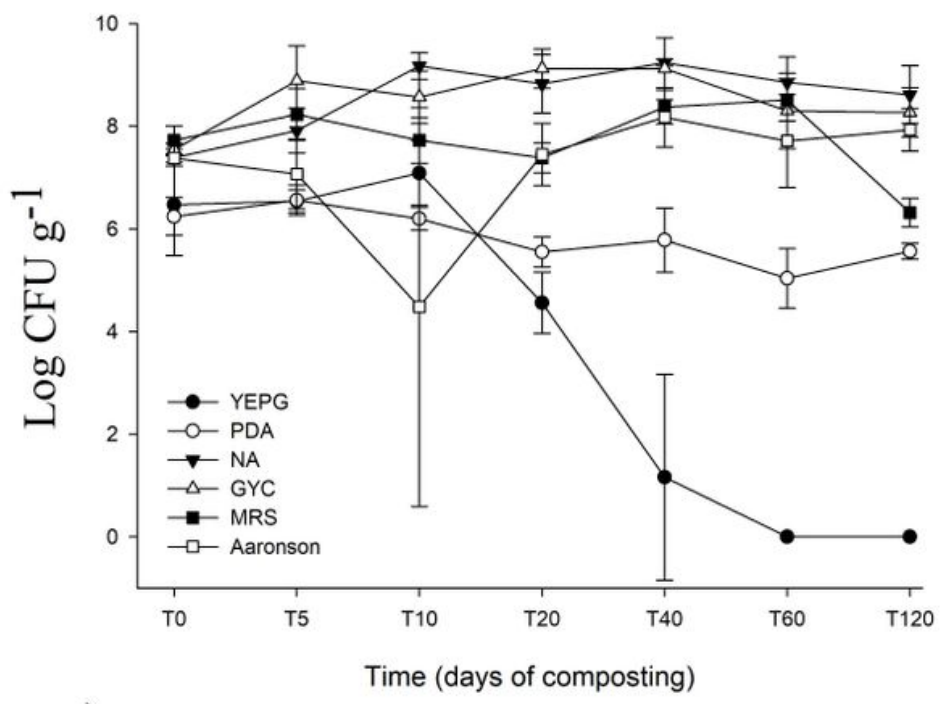

c)

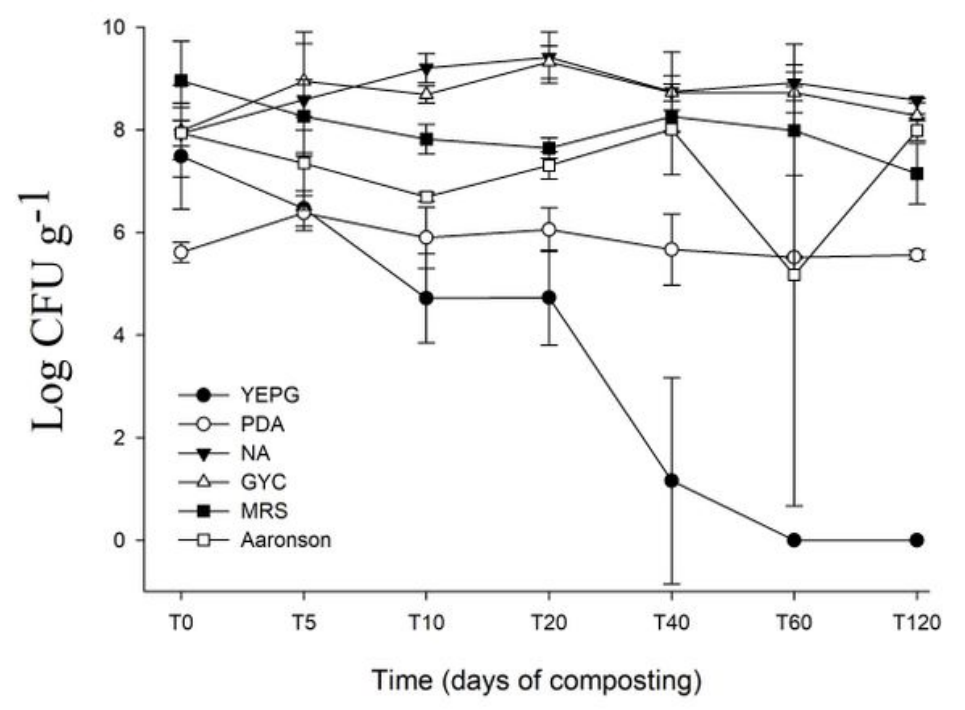

b)

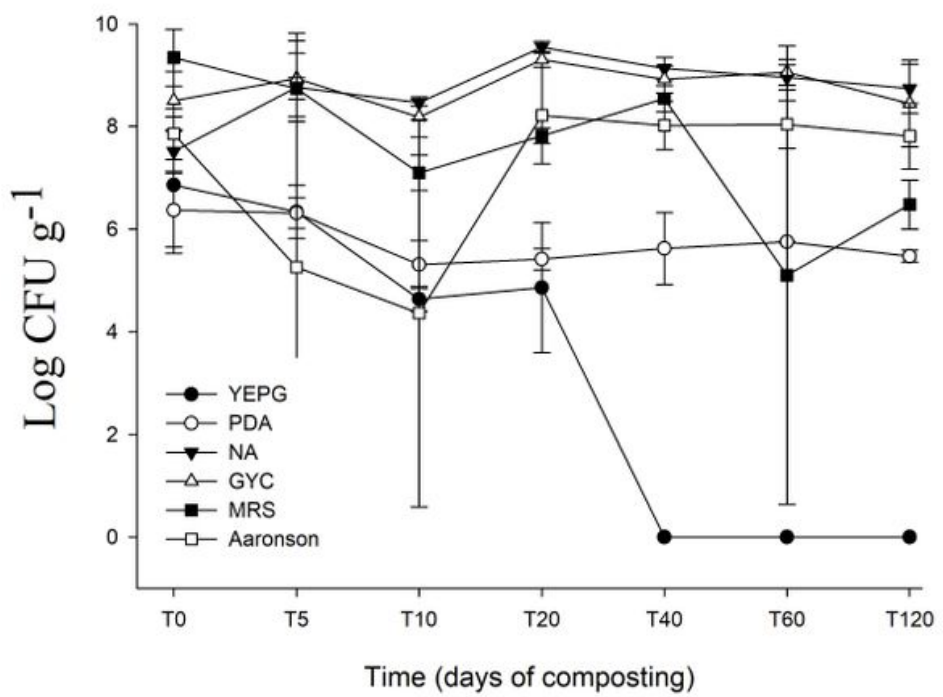

\section{Figure 4}

Variation in the total count of microorganisms (log UFC g-1 of compost) during composting. a) Treatments with efficient microorganisms; b) Control treatment; c) Treatment with commercial inoculum. Means: YEPG - yeast; PDA - Filamentous fungi; NA - Total mesophilic bacteria; MRS - Lactic bacteria; GYC - Bacteria of acetic acid and Aaronson - Actinobacteria.

\section{Supplementary Files}

This is a list of supplementary files associated with this preprint. Click to download.

- Supplementarymaterial03.04.docx 